\title{
Influences of Implementation of the Village Status Changes Policy and Administrative Village Head Leadership toward Hinterland Community Empowerment in Batam City Riau Island Province
}

\author{
Herman Rozie (Correspondence Author) \\ Government Institute of Home Affairs (IPDN), Indonesia
}

Tjahja Supriatna

Government Institute of Home Affairs (IPDN), Indonesia

Zudan Arief Fakhrullah

Government Institute of Home Affairs (IPDN), Indonesia

Suhajar Diantoro

Government Institute of Home Affairs (IPDN), Indonesia

Received: Oct. 4, 2018 Accepted: Oct. 25, 2018 Online published: Nov. 12, 2018

doi:10.5296/jpag.v8i4.13707

URL: https://doi.org/10.5296/jpag.v8i4.13707

\begin{abstract}
The phenomenon used as the object of research is the empowerment of the hinterland community in Batam City. The objectives of the research are (1) to analyze of the influence of the policy implementation of change statute village toward the empowerment of hinterland community; (2) to analyze of the influence of village leadership master hinterland toward the empowerment of community; (3) to analyze of the influence of the policy implementation of change statute village leadership and village master together toward the empowerment of hinterland community; (4) Obtain a new concept from the discussion of influence of the policy implementation of change statute village toward the empowerment of hinterland community; (5) Obtain a new concept from the influence of the village master leadership
\end{abstract}


toward the empowerment of hinterland community. The research used quantitative research approach; A sample of 220 respondents taken from a population of 1574 people using SEM sample size; Data collection using literature study, interview and observation techniques; Data analysis using SEM Analysis and Regression Analysis. The Conclusions are the following: The amount of influence of the policy implementation of change statute village toward the empowerment of community hinterland Reaches 0.65 , is determined by the content of policy andcontext of Implementation. The amount of influence of village master leadership toward the empowerment of community Reaches 0:54 hinterland, is determined bypersonality, Role, organization, task, values, and setting. Therefore, influence ofthe policy implementation of change statute village leadership and village master together toward the empowerment of hinterland community. New Concept derived from the discussion of influence of the policy implementation of change statute village toward the empowerment of hinterland community is the new concept I about the context of implementation of basic government policy. New Concept derived from the discussion of influence of the village master leadership toward the empowerment of community hinterland II is the new concept about leadership behavior bureaucracy setting.

Keywords: policy implementation, master village leadership, community empowerment

\section{Introduction}

Batam City Government established by Law No. 53 of 1999. With the publication of Law No. 25 of 2002 on the establishment of Riau Islands Province Batam then became one of the autonomous region under the Riau Islands Province ("Undang Undang Nomor 53 Tahun 1999 tentang Pembentukan Kota Batam," n.d.) ("Undang Undang Nomor 25 Tahun 2002 tentang Pembentukan Provinsi Kepulauan Riau," n.d.). Vision Batam Year 2016-2021 is "The World Bandar Madani Batam As powerful Competitiveness, Forward, Welfare and Dignity". With this vision, mission Batam are (1) Achieve Good Governance, Clean, Transparent, Accountable and Protects; (2) Delivering HR Devoted, Competitive and Prosperous Communities; (3) Realizing Spatial Environmental, Infrastructure Urban Modern and Friendly Settlement Arrangement; (4) Achieve Industry Sector Strengthening and Improving Service Sector, Trade, Tourism, Alihkapal, Maritime and Agriculture / Fisheries in Sustaining Regional Economy; (5) Creating the Economy Strengthening Democracy based SMEs and cooperatives that Synergy with the Industrial and Domestic Market Needs; and (6) Realizing the Acceleration of Development in the Region Hinterland as Sustainer and Economy Stand Batam.

With six of the mission, the mission of "Creating the Acceleration of Development in the Region Hinterland as Sustainer and Economy Stand Batam" seems to be associated with changes in the status of rural areas into urban hiterland. The change of status is set in the village area of Batam City Regional Regulation No. 4 of 2002 Regarding Status Changes Become village Village. The regulation is based on the entire village in the city of Batam transformed into villages, including villages in the hinterland. The village is transformed into villages in the hinterland region amounted to 16 villages, namely (1) Village Ngenang be Kelurahan Ngenang; (2) Village Sijantung be Kelurahan Sijantung, located in the sub-District 
Sijantung Galang; (3) Village Karas be Kelurahan Karas; (4) Galang Baru Village be Kelurahan Galang Baru; (5) Sembulang Village be Kelurahan Sembulang; (6) Rempang cate village be kelurahan Rempang cate; (7) Subang Mas Village be Kelurahan Subang Mas; (8) Pulau Abang village be Kelurahan Pulau Abang; (9) Pemping Village be Keluarahan Pemping; (10) Kasu Village be Kelurahan Kasu; (11) Pecong Village be Keluarahan Pecong; (12) Pulau Terong Village be Kelurahan Pulau Terong; (13) Temoyong Village be Kelurahan Temoyong; (14) Batu Legong village be Kelurahan batu Legong; (15) Pantai Gelam Village be Kelurahan Pantai Gelam; and (16) Setotok Village be Kelurahan Setotok ("Peraturan Daerah Kota Batam Nomor 4 Tahun 2002 tentang Perubahan Status Desa menjadi Kelurahan,” n.d.).

With an area reaching $3.990 .00 \mathrm{~km} 2$ of land area comprises $1,040 \mathrm{~km} 2$ and sea area of 2,950 $\mathrm{km} 2$, the population of the city of Batam in 2015 there were 1,037,187 people, consisting of 638404 male inhabitants or 51.67 per cent, and 597247 or 48.33 percent female soul. With a population exceeding one million people of Batam looked into society hetoregen and dynamic social changes. One social change visible in the implementation of the Government of Batam are social changes arising from the dynamics of community empowerment hinterland Batam. Community empowerment in Batam city's hinterland is crucial for the realization of sovereignty in the border region. State sovereignty is of course not limited to the scope of the territorial defense; but covers also the country's sovereignty in the political, legal, social, cultural, and economic. Therefore, given that there are some people living in the hinterland of the outermost small islands, the hinterland community empowerment in Batam city is also related to government policy on border management.

Community empowerment hinterland in Batam not only from the changes in social norms and social behavior, but it is also evident from the shifting role of social institutions. The shifting role of social institutions in question, among other things as a logical consequence of the introduction of decentralization and regional autonomy policies for areas of the city. For example, changes in the status of the village into the village clearly raises the changing role of social institutions that directly or indirectly impact on social life masyarakarat. Meanwhile, the dynamics of community empowerment hinterland in Batam seemed to be a phenomenon dynamics of community life that can not escape the influence of various variables. Among a number of variables that affect.

\section{Literature Review}

\section{Policy Implementation Status Change Village}

Grindle (Grindle, 1980) say that the results of policy implementation powerful influence on society, individuals and groups as well as changes and acceptance of change dipengaruh by the contents of wisdom (content of policy) and policy implementation context (context of implementation). The contents policies include (1) interests affected; (2) types of benefits; (3) The extent of change envisioned; (4) site of dicision making; (5) program implementers; and (6) resource commited. The context of the implementation includes: (1) power, interests, and strategies of actors Involved; (2) The institution and regime characteristic; and (3) compliance and responsiveness. In other side, Dye (Dye, 1987) said that policy implementation is whatever government choose to do or not do. It is mean that government as 
policy maker has an authority to do something or not to do something which is absolutely caused for the public as policy object. So that, Anderson (Anderson, 2010) said that "...In general usage, the term policy designates the behavior of some actor or set of actors, such as an official, a governmental agency, or a legislature, in an area of activity such as public transportation or consumer protection. Public policy also may be viewed as whatever governments choose to do or not to do". Anderson explain that policy is linked with actor's behavior in public sphere. Additionally, Grindle also said that "In general, the last of implementation into establish a link that allows the goals of public politics policies to be realized as outcomes of governmental activity. It involves, therefore, the creation of a "policy delivery system", I which specific means are designed and pursued in the expectation of arriving at particular ends. Thus, public policies - board statements of goals, objectives, and means - are translated into action programs that aim to achieve the ends stated in the policy. It is apparent, then, that a variety of programs may be developed in response to the same policy goals. Action programs themselves may be disaggregated into more specific projects to be administered. The intent of action programs and individual projects is to cause a change in the policy environment, a change that can be considered an outcome of the program". It is mean that web of actor in policy implementation is an important aspect in order to make the policy purpose reached.

Based on the theory Grindle prepared conspetual definition of variables that village Status Change Policy Implementation is the execution of Batam City Regional Regulation No. 4 of 2002 on the Status Change Village Being the Village that was revealed by the content of the policy and the context of implementation. Conceptual definition of variables derived from the two-dimensional analysis: (1) Analysis of the content of the policy and (2) Analysis of the context of implementation.

\section{Leadership of Administrative Village Head}

Paige in rasyid (Rasyid, 2000) introduced a scientific approach by presenting six main things that need to be researched in the study of leadership of the government, namely: personality, role, organization, task, values, and setting. Other definition about leadership is explained by Kouzes \& Posner (Kouzes \& Posner, 2007) as a process whereby one person exerts social influence over the members of a group. A leader is a person with power over others who exercises this power for the purpose of influencing their behavior. Broadly, Wirjana and Supardo (Wirajana \& Supardo, 2005) gives six ideal concept of leadership, namely:

1. That everyone has a patency to develop. Thus a leader is obliged to actualize the potential of the people they lead optimally, primarily and especially for the good of them and the organization.

2. What is different but related to the principle above is the principle called solidarity and subsidiarity. Our solidarity has understood its meaning, solidarity with each other. What is still not understood and appreciated is subsidiarity, a principle that is now often called "self-help", in the sense that decisions concerning the fate and life of a particular group or community must be taken by themselves and not decided by other leaders or groups. 


\section{Macrothink}

Journal of Public Administration and Governance

3. Loving others taught by all religions is a norm of universal behavior, which is positive love for others, as well as those who are led. Leaders must have a caring attitude, which is a positive loving attitude, because if they care they will do something to alleviate the suffering experienced by their people.

4. Accountability must be a principle held by the leader and demanded by the person in charge. Accountability makes one's leadership valuable and valued by the leader. Basically accountability is fulfilling the promises that have been made, as well as fulfilling the commitments that have been given, accountable for what has been done in relation to how he uses the authority that has been given to him.

5. Ideal leadership is leadership that puts life as a service and not just a career. At this time we see how much the community needs for service, especially from leaders.

6. Leadership involves the willingness and ability to change, a dynamic and not static attitude. This is necessary because in reality everything changes. Because what doesn't change is change itself. In this millennium, leaders are required to have a vision, courage, and at the same time remain humble to remain willing to learn and grow.

Based on the theory Paige arranged konspetual definition of variables that Lurah Leadership is leadership of the government that existed between the village chief and village device with the community in the implementation of community development activities revealed by personality, role, organization, task, values, setting. Conceptual definition of variables derived from the six dimensions of analysis: (1) Analysis of personality, (2) Analysis of the role, (3) Analysis of the organization, (4) Analysis of the task, (5) Analysis of values, and (6) Analysis of the setting.

\section{Hinterland Community Empowerment}

Ife (Ife, 1995) says "Empowerment means providing people with the resources, opportunities, knowledge and skills to increase of Reviews their capacity to Determine Reviews their own futures, and to Participate in and effect the life of Reviews their community". Such participation is not only aimed at decisions about the project, more than that the ability to participate as a form of community empowerment will be able to contribute to the implementation of sustainable development. This can be achieved if empowerment is carried out to explore and grow various fields of community expertise that can be used in socio-economic data collection, monitoring and evaluating projects, checking socio-cultural truths collected by outsiders, providing technical knowledge and contributing space and historical information about previous projects that might be similar and the causes of their success or failure. Hulme \& Tulme in Pranarka (Pranarka, 1996) also gives definition about empowerment which is influencing the social change. They said "Empowerment encourages a process of social change that allows marginalized people who are powerless to give greater influence in the political arena locally and nationally. Therefore, empowerment is individual and collective. Empowerment is also a process that involves power relations that change between individuals, groups and social institutions. Empowerment is also a process of 
personal change, because each individual takes action on their own behalf and then reinforces his understanding of the world in which he lives".

Based on the theory of Ife konspetual structured variable definitions thatHinterland Community Empowerment is a series of efforts to strengthen the resources of individuals, families and communities are revealed hinterland of provision resources, opportunities, knowledge and skills to increase the capacity in determining the future and participate in their environment. Conceptual definition of variables derived from the four dimensions of analysis: (1) Analysis of pMaking available resources, (2) Analysis of the provision of opportunities, (3) Analysis of the provision of knowledge, and (4) Analysis of the supply of skills.

\section{Method}

There42 manifest variables were developed from three latent variables used 42 item questionnaire study. The preparation of the questionnaire using Likert Scale. Questionnaires were administered to a sample of 210 respondents were obtained from 5 x 42 SEM measurement parameters according to the formula. The sampling distribution of each sub-population / unit analysis using Rendom Stratified Sampling Technique. Secondary data collection of books and documents using literature study. The collection of primary data from samples of research using questionnaires and observation techniques. Technical Data Analysis using SEM analysis methods (Structural Equation Models) with the stages of the application consisting of (1) specification models, (2) Identification, (3) estimates, (4) Test Matches, (5) Respesifikasi. The results of SEM analysis was then developed with a descriptive analysis to obtain research findings that form the basis of a new concept. The findings were obtained from the Confirmatory Factors Analysis (CFA).

\section{Results and Discussion}

\section{Analysis of Effect Measurement Result Status Change Policy Implementation Community Empowerment against Rural Hinterland}

The amount of influence Implementation Status Change Hinterland Village Community Empowerment Against reach0.65. Effect of Change Policy Implementation Status Hinterland Village Community Empowerment Against fairly strong, positive and significant. The amount of influence Implementation Status Change Empowerment Against Rural Hinterland proved to be determined by the Content of Policy and Context of Implementation. With such evidence, it can be argued the meaning and interpretation of research results that terbentuknya influence Policy Implementation Status Change Village is positioned antecedent variables against Hinterland Community Empowerment which is positioned as a consequence variable indicates the establishment of a causal relationship (causality). The causal relationship means that if the village Status Change Policy Implementation improved or increases, the increase was followed by an increase in Region Hinterland Community Empowerment. The research proves that the Rural Policy Implementation Status Change causal factors increase or decrease in community empowerment Hinterland area in Batam.

Increased community empowerment in the Hinterland region can be done by improving the effectiveness of policy implementation change in the status of the village as the local 
regulation of Batam No. 4 of 2002 on the Status Change Village Being the Village. Increasing the effectiveness of the implementation of the wisdom of village status changes include 12 indicators of effectiveness, namely (1) The interests that influence; (2) Type of benefit; (3) The degree of the changes described; (4)Location of decision-making; (5) Implementing the program; (6) The commitment of resources; (7) The authority of the parties involved; (8) The interests of the parties involved; (9) The strategy of the parties involved; (10) The characteristics of the officials and institutions; (11) The fulfillment of the needs of the community; and (12) The response to the expectations of society.

Novelty obtained from the analysis of the influence of Rural Policy Implementation Status Changes to the Hinterland Community Empowerment is about Context Implementation of Government Policy Bottom defined as a pattern and direction of the implementation of the policy of the government bureaucracy bottom is done with authority, interests, strategies, institutional characteristics to meet the needs of the community and respond to the expectations of local communities that took place in the implementation of government affairs. In this definition included four theoretical dimensions: (1) The dimensions of the Authority; (2) Interest Dimensions; (3) Dimension Strategy; and (4) Dimensions institutional characteristics to meet people's needs and respond to the expectations of society.

Government Policy Implementation Bottom context which is seen as a pattern and direction of the implementation of the policy of the government bureaucracy bottom is done with authority, interests, strategies, institutional characteristics to meet the needs of the community and respond to the expectations of local communities in the implementation of government affairs could be crucial in local governance. The importance of patterns anddirection of policy implementation of government bureaucracy bottom deemed important because the pattern and direction of the implementation of these policies can spearhead the implementation of government functions, especially at the lower government which is in the border area as kelurahan located in Batam City Hinterland region or area- other areas in Riau Islands province and other areas. In addition to spearheading the implementation of government functions; pattern and direction of the implementation of government bureaucracy bottom aligned with the dynamics of community development and social change can also be a choice of democratic governance strategy to optimize the management of various aspirations, potentials and public participation. Therefore, authority, interests, strategies, and institutional characteristics appropriate to meet the needs of the community and respond to the expectations of the local community. Thus there are four practical dimensions in the preparation of the pattern and direction of implementing the policy, namely: Authority, interests, strategies and institutional characteristics of the bottom of the government bureaucracy.

Government bureaucracy Bottom authority in question isformal authority of the government bureaucracy bottom organizers focused on efforts to meet people's needs and responding to the expectations of local communities to governance. There are three types of formal authority in question are structural authority, the authority of sectoral and functional authority. Structural authority in governance consists of the head of local authority, the authority of district and authority of the headman or village chief as well as business partners Lurah or 
Kepala Desa. Sectoral authority in governance is the authority of regional technical agencies such as Head Units (SKPD). Functional authority is the authority functional officials in various government functions. The third type of formal authority should be seen as an integral element of a functioning government bureaucracy leadership, directing and controlling the implementation of government affairs is the duty area. In such a view, the implementation of the consultation function, the function of coordination and integration functions could be crucial in the implementation of the authority of government briokrasi bottom to create the pattern and direction of the implementation of government policies and practices that are effective, efficient and accountable. Among the three types of authority, in the context of the implementation of government bureaucracy bottom, authorities Lurah or Kepala Desa implementation consulting function, the function of coordination and integration functions could be crucial in the implementation of the authority of government briokrasi bottom to create the pattern and direction of the implementation of government policies and practices that are effective, efficient and accountable. Among the three types of authority, in the context of the implementation of government bureaucracy bottom, authorities Lurah or Kepala Desa implementation consulting function, the function of coordination and integration functions could be crucial in the implementation of the authority of government briokrasi bottom to create the pattern and direction of the implementation of government policies and practices that are effective, efficient and accountable. Among the three types of authority, in the context of the implementation of government bureaucracy bottom, authorities Lurah or Kepala Desais a dominant factor of government leadership to communicate with the local community. Therefore, the government authority attached to the office of headman or village chief should be placed optimally and can be implemented effectively to carry out the functions of government, To that end, the commitment and leadership behavior headman or village head should always be based on the concept of the understanding that the authority of the position actual state mandate that must be implemented in a straight line with the norms and ethics office. Therefore, implementation authority functions Lurah or Kepala Desa in governance, development, community development and public services be constructive and effective. In this context, the implementation of the authority of the headman or village head would be able to spearhead an effective government in meeting the needs of society as well as to respond to people's expectations of the government.

Government bureaucracy Bottom interest in question isaspirations, expectations or needs dukungnadministrative and technical assistance to implement the policies and activities of government through the implementation of institutional duties and functions of government bureaucracy bottom. Administrative support may include support personnel resources, budget allocations support the performance, regulatory support and the support means infrastructures. Technical assistance may include technical assistance operational managerial and technical assistance to implement the government's policies and activities. The more optimal administrative support and technical assistance received by the government bureaucracy, the more optimal bottom also the implementation of policies and activities of the government.In this context, the thing to understand is that the administrative support and technical assistance that not everything can be expressed explicitly by certain circumstances; but still there and cumbersome implementation of government policies and activities. Therefore, certain 
approaches were needed to establish a mutual understanding that each party feels attention and response as appropriate. At the village or the village of these approaches is the duty headman or village chief. Meanwhile, the interests of the stakeholders involved in the implementation of government policies and activities should be seen as a logical consequence that needs disekapi appropriately. In such a view, the implementation of the consultation function.

Bottom Government Bureaucracy strategy in question istips and levels of the ways to achieve certain goals that do bureaucratic work units in implementing government policies and activities. On the one hand, kiat and levels of the ways to achieve a particular goal is a strategic management measures undertaken in the implementation of various programs and specific activities. Programs and activities referred to necessarily targeted to meet the needs of the community and respond to the expectations of society against the government. In practical dimensions, tips and levels of the ways to achieve this particular goal is done by way of organizing, directing and controlling the use of administrative resources and application management functions of government strategy. Administrative resources may include personnel resources, budget resources, resources and regulatory infrastructure resources. Yangdimaksud management functions include planning, organizing function, the function of the implementation, the monitoring function, and accountability functions. The use of administrative resources should be transparent, effective, efficient and accountable. While the implementation of the management functions of the government strategy should be coordinated and connected to all sectors and levels involved in the implementation of government policies and activities. In this context, regardless of the strategy adopted in the implementation of government strategies bottom management, goals must be related to the needs of the community and also related to the people's expectations of the government. While the implementation of the management functions of the government strategy should be coordinated and connected to all sectors and levels involved in the implementation of government policies and activities. In this context, regardless of the strategy adopted in the implementation of government strategies bottom management, goals must be related to the needs of the community and also related to the people's expectations of the government. While the implementation of the management functions of the government strategy should be coordinated and connected to all sectors and levels involved in the implementation of government policies and activities. In this context, regardless of the strategy adopted in the implementation of government strategies bottom management, goals must be related to the needs of the community and also related to the people's expectations of the government.In this case, you need to understand is that tips and levels of the ways to achieve a particular goal was a series of duties and functions of the working units of government bureaucracy bottom interrelated. Therefore, the necessary implementation consulting function, the function of coordination and integration of optimal function of each unit of bureaucratic work. Thus each unit can find support to carry out the roles and responsibilities optimally. The effectiveness of the implementation of the function of consultation, coordination function and the function of this integration is the duty headman or village chief.

Government bureaucracy Bottom institutional characteristics in question is a description of 
the scope of the powers, duties and functions of village or village that characterize the institutional bureaucracy in the lowest level. Jika seen from the position which is located at the lowest level, institutional characteristics of the village or the village tend to act as the cutting edge of governance in the region; and even directed to become the frontline of government. This role certainly has consequences in itself, since dealing directly with the dynamics of community development and social change. With urban governance policies geared to accelerate the realization of the people's welfare through the improvement of service, empowerment and participation of local communities with regard to principles of democracy, equality, justice, and the peculiarities of an area, thenGovernment bureaucracy Bottom institutional characteristics must be optimized. This optimization, among others carried out by adjust the shape and susuananVillage government or village administration to the shape and composition of the regional organizations at the district / city. Thereforescope of authority, duties and functions in harmony with the village or the village of the authority, duties and functions of the regional work units at the district / city. This is characteristic of institutional government bureaucracy bottom needs to be built in line with the reform agenda of the bureaucracy and the enactment of legislation on the village.Moreover, given that village or villages in the border area, it is directly or indirectly the implementation of other government functions is also connected with the implementation of the authority, duties and functions of the village or the village. Governmental functions in question are government functions related to the efforts to achieve the country's sovereignty and territorial integrity of the Republic of Indonesia at the border.With this reality, then the implementation of the consultation function, the function of coordination and integration functions could be crucial in optimizing Lurah role or the role of the village chief in the tasks and functions of government bureaucracy bottom as the spearhead of governance in the border area.

\section{Leadership Influence Measurement Result Analysis Lurah against Hinterland Community Empowerment}

The amount of influence on the Empowerment Leadership Lurah Hinterland reach 0.54.Leadership Influence Lurah on Community Empowerment in Hinterland area is quite strong, positive and significant. The amount of influence on the Lurah Leadership Empowerment in Hinterland Region proved to be determined bypersonality, role, organization, task, values, and setting. With such evidence, it can be argued the meaning and interpretation of research results that terbentuknya influence Lurah Leadership which are positioned antecedent variables against Hinterland Community Empowerment which is positioned as a consequence variable indicates the establishment of a causal relationship (causality). The causal relationship means that if Lurah Leadership enhanced or increases, this increase followed by an increase in Region Hinterland Community Empowerment.

The research proves that the leadership Lurah be factors increasing or decreasing Hinterland community empowerment in Batam. Increased Hinterland community empowerment can be done by improving the effectiveness of Leadership Lurah. Increasing the effectiveness of leadership Lurah include 12 indicators of leadership effectiveness, namely (1)Exemplary Lurah, (2) ability Lurah, (3) Imaging Lurah, (4) The political role Lurah, (5) social role Lurah, (6) The role of culture Lurah, (7) Structure Village Office, (8) Function Village Office, (9) 
The task of the Village Office, (10) Platform duty of Administrative VillageHead (11) details of task Lurah (12) Implementation Lurah (13) Value mobilization, (14) Value guidance, (15) Value of control, (16) Decision decision, (17) Direction, and (18) Control.

The concept gained from the analysis of the influence of Kepemipinan Lurah against Hinterland Community Empowerment is about Structuring Leadership Behavior Bureaucracy is defined as a set or pattern of leadership behavior associated with urban bureaucratic decision-making, direction and control of government affairs. In this definition included four theoretical dimensions: (1) Dimensional Decision; (2) Dimensions Direction; and (3) Dimension Control.Setting or village bureaucratic leadership behavior patterns associated with decision-making, directing and controlling the implementation of government affairs is one of the determinants of the effectiveness of the implementation of governance, development, empowerment and service in the village. In this context, setting or bureaucratic leadership behavior patterns inherent in the role of the village headman as the helm of the government bureaucracy bottom, Lurah role as manager of the implementation of government policies and activities; and the role of the village headman as head of the region directly opposite the dynamics of community development and social change.In this perspective included three theoretical dimensions: (1) Dimensional Decision; (2) Dimensions Direction; and (3) Dimension Control.

The decision is the decision-making procedures that are strategic Lurah done to address the problems that arise in implementing specific policies and activities of government. The procedure is certainly not only related with the necessary information to make decisions; but also related to the importance of coordination or involvement of the various parties concerned with the decision-making process and the use of resources to implement the decision. Decision is considered to be strategic if the decision concerning the interests of the government and or raises issues that affect many people. This decision-making tasks and responsibilities Lurah as the helm of the government bureaucracy bottom. The decision-making context can be associated with the position of headman as the helm, Head as a manager, and Lurah as Head of Region. Lurah as top looks he became a top figure in the organization of the government bureaucracy bottom; and therefore Lurah have to be smart and careful in taking decisions to solve specific problems that are considered to pose a widespread influence. In this dimension, Head must be clever formulate appropriate strategies to implement decisions effectively. Strategy formulation is able to use factor analysis method SWOT consisting of: (1) the analysis of force (stranght) that support the effective implementation of decisions; (2) analysis of weakness (weakness) in the formulation and implementation of the decision; (3) analysis of peluan (oppurtinties) needed untukmelaksanakan decisions effectively; and (4) an analysis of the threat (treat) that must be anticipated that a decision can be implemented effectively. Lurah as manager he seemed to become a top figure in the implementation of urban management functions; and therefore should be smart and observant Lurah control and coordinate the implementation of the management functions. Management functions in question are (1) the functions of planning (planning) are institutionally structured in the form of the Organization's Strategic Plan (Plan) and the Annual Work Plan and Budget Sub; (2) the function of organizing (organizing) were 
institutionalized into working units bureaucracy village; (3) function implementation (actuiting) that make up the performance of each job or activity; (4) The coordination function (coordinating) implementations that integrate the work or activity; (5) the budget function (budgeting) allocated to each job or activity; and (6) the function of the accountability report (reporting) were institutionalized called Government Agencies Performance Accountability Report. If there are problems or emerging obstacles that led to the implementation of the management functions are not working as it should, then the headman should immediately drive decision-making to overcome problems or constraints. Decision making is first priority at the device level kelurahah unit leader. If at this level the decision is not reached, because of problems or obstacles that dimuncul involving several units, and a variety of resources, then Lurah need immediate intervention. That is, the direct role Lurah decisions. Lurah as Head of Region is a top figure in the implementation of government affairs in the village; Lurah and therefore must be good at doing social approaches in serving the needs of society and at the same time respond to the aspirations of the people. In this dimension, certainly not all of the performance of services and the response to the aspirations can be performed optimally. Therefore, Lurah need to make decisions to optimize the performance of services and response. Lurah success in taking decisions, among others revealed by the compliance and the ability of staff to implement the decision. From a situation of success decision is then awakened villages performance in implementing government affairs. The village of performance consists of the execution of the work and results of the implementation work. The process of implementation of the work the village can be judged by the work productivity, effectiveness of activities, efficient use of financial resources, and accountability of the implementation work. The results of the work of the village can be judged from the aspect of quantity and quality aspects as well as aspects of the benefits and impact of the implementation work. Therefore, the village chief's role as the helm of the process of return for the decision needs to be optimized. With the role as the helm of the organization of the government bureaucracy bottom of the face directly with the dynamics of community life, then by itself Lurah ability to make decisions that are strategic to be optimized. In this context, as the helm of the government bureaucracy bottom in charge of implementing government affairs, Head of dealing directly with stakeholders should be good at taking decisions carefully, tapat and can be effectively implemented. In this context, the ability Lurah in taking the right decisions, careful and effective implementation could be crucial. That is, functionally decision will depend on the capacity and integrity of Lurah leadership itself. Therefore, personalized and functional, Head must be able to take decisions of a strategic nature.

Direction is the determination and explanation towards the implementation of government policies and activities that require special handling. Determining the direction associated with the implementation of administrative needs; while explanations direction associated with the implementation of technical requirements. Lurah briefing on the implementation of government policies and activities, it is vital that the process of implementing the policies and activities support sufficient resources and be effective. This Lurah related directives as top notch headman, village chief as the manager, and Lurah as Head of Region. Lurah pinnacle of leadership in the implementation of the working units of government bureaucracy bottom 
should provide a clear direction and firm so that everything that is needed to implement effective policies and activities can be prepared in advance. In this dimension, Head must be clever and smart in directing the work behavior and the use of devices village resource allocation policies. Lurah as managers in the implementation of the management functions of government need to give directives bottom of a clear and unequivocal so that everything that is needed to implement effective policies and activities can be prepared in advance. Management functions of government need to be prepared to implement effective policies and activities are: (1) the functions of planning (planning) are institutionally structured in the form of the Organization's Strategic Plan and the Annual Budget and Work Plan for the Village; (2) the function of organizing (organizing) were institutionalized into working units bureaucracy village; (3) function implementation (actuiting) that make up the performance of each job or activity; (4) The coordination function (coordinating) implementations that integrate the work or activity; (5) the budget function (budgeting) allocated to each job or activity; and (6) the function of the accountability report (reporting) were institutionalized called Government Agencies Performance Accountability Report. Implementation of management functions transparent, effective, efficient and accountable in the process of implementation of government policies and activities can be achieved when determining the direction and explanation of policy direction can be conveyed clearly and firmly to the staff. Lurah as Head of Region needs to give a clear direction and firm so that the parties involved in the process of implementation of policies and activities to understand the role of government involvement. For that Lurah should undertake social approaches to the various parties concerned. Lurah success in directing the work behavior of staff implementing government policies and activities, among others revealed by the compliance staff on the rules, direction and control of Lurah. The more obedient staff on the rules, direction and control Lurah, the more successful in driving behavior Lurah work of staff implementing policies and government activities that require special handling. From a situation briefing here awakened success villages performance in implementing government policies and activities that require special pennaganan. The village of performance consists of the execution of the work and results of the implementation work. The process of implementation of the work the village can be judged by the effectiveness of activities, efficient use of resources, especially financial resources, and accountability for implementing the policy. The results of implementation of the work can be judged from the aspect of quantity and quality aspects as well as aspects of the benefits and impact of the implementation work. Therefore, the village chief role as a steering device work behavior villages need to be optimized. Lurah ability in directing the behavior of the staff work required a coordinated, effective, efficient and accountable, both in the context of the internal and external context. Implementation of such Lurah task was certainly not easy. In the implementation of government affairs, especially matters into direct assignment village, of course there are many factors that must be taken into account. Factors that question can consist of internal resources and external resources Village Office. Internal resources in question are personnel resources, budgetary resources, policy resources and infrastructure resources. Technical implementation of the tasks Lurah course depend on the condition of these internal resources. Meanwhile, external factors also influence the Village Office technical execution of tasks such Lurah task. As the 
lower helm of government bureaucracy in charge of implementing government affairs, Lurah dealing directly with stakeholders should demonstrate the capacity and integrity clever in directing the work behavior of staff implementing policies that require special handling. In this context, the ability Lurah in directing the behavior of staff could be crucial. That is, functionally briefing conducted Lurah it relies on leadership competencies Lurah itself. Therefore, personalized and functional, Head should be able to guide the behavior of staff. In this context, the ability Lurah in directing the behavior of the staff working in the area of empowering communities Hinterland Batam. functionally briefing conducted Lurah it relies on leadership competencies Lurah itself. Therefore, personalized and functional, Head should be able to guide the behavior of staff. In this context, the ability Lurah in directing the behavior of the staff working in the area of empowering communities Hinterland Batam. functionally briefing conducted Lurah it relies on leadership competencies Lurah itself. Therefore, personalized and functional, Head should be able to guide the behavior of staff. In this context, the ability Lurah in directing the behavior of the staff working in the area of empowering communities Hinterland Batam.

Control is supervising and monitoring the activities undertaken by the village chief to the implementation of government policies and activities. Supervision needs to be done by the village chief on the performance of resources, particularly the performance of apparatus and the performance of the budget, so that the performance of these resources can be dipertanggungjawabakan. Monitoring needs to be done by the village chief to the procedures and technical implementation of policies and activities in order to remain coordinated. Lurah Control on the implementation of government policies and activities, it is vital that the process of implementation of policies and activities continue as they should. This corresponds Lurah Control Lurah as top notch, Lurah as manager, and Lurah as Head of Region. Lurah pinnacle of leadership in the implementation of the working units of government bureaucracy bottom should exercise control policies and activities can be carried out effectively. In this dimension, Head must be clever and smart in controlling the behavior of staff and the use of budget allocations. Lurah as managers in the implementation of management functions necessary to control the lower government policies and activities can be carried out effectively. Government management functions need to be controlled so that policies and activities can be carried out effectively are: (1) the functions of planning (planning); (2) the function of organizing (organizing); (3) function implementation (actuiting); (4) The coordination function (coordinating); (5) the budget function (budgeting); and (6) the function of reporting (reporting). Implementation of management functions transparent, effective, efficient and accountable in the process of implementation of government policies and activities can be achieved if control over the implementation of the management functions can be performed effectively. Lurah as Head of Region should also exercise control so that the parties involved in the process of implementation of policies and activities to understand the role of government involvement. For that Lurah should undertake social approaches to the various parties concerned. Lurah success in controlling the behavior of the staff working in implementing the policies and activities of the government are revealed by the compliance staff on the rules, direction and control of Lurah. The more obedient staff on the rules, direction and control Lurah Lurah the more successful in 
controlling the behavior of staff implementing the policies and activities of government. This is the control of the situation woke success villages performance in implementing the policies and activities of government. Lurah role as the controlling behavior of administrative staff work needs to be optimized. Lurah ability to control the behavior of the staff work required a coordinated, effective, efficient and accountable. As the lower helm of government bureaucracy in charge of implementing government affairs, Head of dealing directly with stakeholders should demonstrate the capacity and integrity clever in controlling the behavior of staff. In this context, the ability to control the behavior of village chief of staff could be crucial. That is, functionally controlling performed Lurah it depends on the behavior Lurah leadership itself. Therefore, personalized and functional, Head must be able to control the behavior of staff, so that the behavior of its leadership is not in doubt.

\section{Closing}

The amount of influence Implementation Status Change Village to Brick City Hinterland Community Empowerment reach 0.65, remained strong and significant. The amount of influencePolicy Implementation Status Change Village to Hinterland Community Empowerment determined by Content of Policy and Context of Implementation. The effect indicates that among Implementation Status Change Village with Hinterland Community Empowerment in Batam formed causality. Such was their influence means that if the village Status Change Policy Implementation increased or enhanced the increase was followed by an increase in Community Empowerment Hinterland. Therefore, improving the effectiveness of community development in hinterland area of Batam can be improved by increasing the effectiveness of policy implementation change in the status of the village as the local regulation of Batam No. 4 of 2002 on the Status Change Village Being the Village. The amount of influence Lurah Leadershipto Hinterland Community Empowerment Batam reach0.54, is quite strong and significant. The amount of influence on the Lurah LeadershipHinterland Community Empowerment determined by personality, Role, organization, task, values, and setting. The effect indicates that between Leadership Empowerment Lurah with Hinterland Batam formed causality. The influence that such Lurah Leadership means that if increased or enhanced the increase was followed by an increase in Community Empowerment Hinterland. Therefore, improving the effectiveness of community empowerment hinterland Batam can be improved by increasing the effectiveness of leadership Lurah.

The new concept obtained from the analysis of the influence of Rural Policy Implementation Status Changes to the Hinterland Community Empowerment Batam is Context Implementation of Government Policy Bottom defined as a pattern and direction of the implementation of the policy of the government bureaucracy bottom is done with authority, interests, strategies, institutional characteristics to meet the needs of the community and respond to the expectations of local communities that took place in the implementation of government affairs. In this definition included four theoretical dimensions, namely: (1) The dimensions of the Authority; (2) Interest Dimensions; (3) Dimension Strategy; and (4) Dimensions institutional characteristics to meet people's needs and respond to the expectations of society. 


\section{Macrothink}

Journal of Public Administration and Governance ISSN 2161-7104 2018, Vol. 8, No. 4

Knew raft obtained from the analysis of the influence of Leadership Empowerment Lurah against Hinterland Batam is about Structuring Leadership Behavior Bureaucracy is defined as a set or pattern of leadership behavior associated with urban bureaucratic decision-making, direction and control of government affairs. In this definition included four theoretical dimensions: (1) Dimensional Decision; (2) Dimensions Direction; and (3) Dimension Control.

\section{Reference}

Anderson, J. E. (2010). Public Policy Making. USA: Cengage Learning.

Dye, T. R. (1987). Understanding Public Policy. New Jersey: Prentice Hall.

Grindle, M. S. (1980). Politics and Policy implementation in The Third World. New Jersey: Princeton University Press. https://doi.org/10.1515/9781400886081

Ife, J. (1995). Community Development: Creating Community Alternatives, Vision, Analysis and Practice. Australia: Longman.

Kouzes, J. M., \& Posner, B. Z. (2007). The Leadership Challenge (4th ed.). John Wiley and Sons.

Peraturan Daerah Kota Batam Nomor 4 Tahun 2002 tentang Perubahan Status Desa menjadi Kelurahan. (n.d.).

Pranarka, A. M. W. (1996). Pemberdayaan : Konsep, Kebijakan dan Implementasi. Jakarta: CSIS.

Rasyid, M. R. (2000). Makna Pemerintahan - Tinjauan dari segi Etika dan Kepemimpinan. Jakarta: PT. Mutiara Sumber Widya.

Undang Undang Nomor 25 Tahun 2002 tentang Pembentukan Provinsi Kepulauan Riau. (n.d.).

Undang Undang Nomor 53 Tahun 1999 tentang Pembentukan Kota Batam. (n.d.).

Wirajana, B. R., \& Supardo, S. (2005). Kepemimpinan, Dasar-Dasar dan Pengembangannya. Yogyakarta: CV. Andi Offset.

\section{Glosssary}

Lakip : The Report of Performance and Accountability of Government Agency

SKPD : : Local Government Agency

Lurah : Administrative Village Head

Kelurahan : Administrative Village

\section{Copyright Disclaimer}

Copyright for this article is retained by the author(s), with first publication rights granted to the journal.

This is an open-access article distributed under the terms and conditions of the Creative Commons Attribution license (http://creativecommons.org/licenses/by/4.0/). 